\title{
Insecticidal activities of asarones identified in Acorus gramineus rhizome against Nilaparvata lugens (Homoptera: Delphacidae) and Plutella xylostella (Lepidoptera: Yponomeutoidae)
}

\author{
Hee-Kwon Lee, Chan Park ${ }^{1}$ and Young-Joon Ahn ${ }^{1, *}$ \\ Korean Raspberry Experiment Station, Gochang Agricultural Development \& Technology Center, Gochang 585-943, Republic of \\ Korea \\ ${ }^{1}$ School of Agricultural Biotechnology and Research Center for New Bio-Materials in Agriculture, Seoul National University, \\ Suwon 441-744, Republic of Korea
}

(Received 13 June 2001; Accepted 13 May 2002)

\begin{abstract}
The insecticidal activities of compounds derived from the rhizomes of Acorus gramineus against four agricultural insect pests were examined using direct contact application method. The biologically active constituents of $A$. gramineus rhizomes were characterized as the phenylpropenes, cis- and trans-asarones by spectroscopic analyses. Potencies varied according to insect species, compound, and dose. In a test with female adults of Nilaparvata lugens, cis-asarone caused 100,83 , and $40 \%$ mortality at $1,000,500$, and $250 \mathrm{ppm}$, respectively, whereas $67 \%$ mortality was achieved at 1,000 ppm of trans-asarone. Against 3rd instar larvae of Plutella xylostella, cis-asarone gave 83 and $50 \%$ mortality at 1,000 and $500 \mathrm{ppm}$, respectively, whereas trans-asarone at 1,000 ppm showed $30 \%$ mortality. Against female adults of Myzus persicae and 3rd instar larvae of Spodoptera litura, cis- and trans-asarones both were almost ineffective at 2,000 ppm. The A. gramineus rhizome-derived materials merit further study as potential insect-control agents or as lead compounds against $N$. lugens and P. xylostella.
\end{abstract}

Key words: Natural insecticide, Nilaparvata lugens, Plutella xylostella, Acorus gramineus, asarone

\section{INTRODUCTION}

Over several decades, insect pests have been controlled mainly by synthetic insecticides. Although effective, their repeated use has disrupted natural biological control systems and led to resurgence of insect species, sometimes resulting in the development of resistance, undesirable effects on non-target organisms, and fostered environmental and human health concerns (Brown, 1978; Georghiou and Saito, 1983; Hayes and Laws, 1991). These problems have highlighted the need for the development of new strategies for selective insect pest control.

Plants may provide potential alternatives to currently used insect-control agents because they constitute a rich source of bioactive chemicals (Wink, 1993). Much effort has been focused on plant-derived materials as potential sources of commercial insect-control agents or as lead compounds (Arnason et al., 1989a; Miyakado et al., 1989; Isman, 1995; Hedin et al., 1997). Jacobson (1989) has pointed out that the most promising botanical insect-control agents are in the families Annonaceae, Asteraceae, Canellaceae, Labiatae, Meliaceae, and Rutaceae. Methanol extract of the rhizomes from Acorus gramineus Solander, belonging to the family Araceae, has insecticidal activity against female adults of Nilaparvata lugens (Stål) and larvae of Plutella xylostella (L.) (Kim et al., 2001).

In the laboratory study described herein, we have examined the methanol extract of the rhizomes from $A$. gramineus for insecticidal constituents active against four economically important agricultural insect pests [N. lugens, Myzus persicae (Sulzer), P. xylostella, and Spodoptera litura (F.)] using direct contact application method.

\section{MATERIALS AND METHODS}

Chemicals. cis- and trans-Asarones were purchased from Aldrich (Milwaukee, WI, USA). Triton X-100 was supplied by Coseal (Seoul, Korea). All other chemicals were of reagent grade.

\footnotetext{
* To whom correspondence should be addressed at: E-mail: yjahn@snu.ac.kr
} 
Insects. The susceptible strains of $N$. lugens, $M$. persicae, and $P$. xylostella have been maintained in the laboratory without exposure to any insecticide on Oryza sativa L. seedlings (7-10 days after germination), Nicotiana tabacum L., and Raphanus sativus L. seedlings (5-6 days after germination), respectively, in acrylic cages at $25 \pm 1{ }^{\circ} \mathrm{C}, 40-60 \%$ $\mathrm{RH}$, and a photoregime of $16: 8(\mathrm{~L}: \mathrm{D}) \mathrm{h}$. The laboratory-reared strain of $S$. litura was reared on an artificial diet (Im et al., 1988) in plastic containers $(28 \times 20 \times 9 \mathrm{~cm})$.

Isolation and identification. Dried rhizomes (5 kg) of A. gramineus were purchased from Boeun medicinal herb shop, Kyungdong market, Seoul. It was finely powdered, extracted twice with methanol $(20 l)$ at room temperature and filtered. The combined filtrate was concentrated under vacuum at $45^{\circ} \mathrm{C}$ to yield about $15 \%$ (based on the weight of the dried rhizome). The extract $(40 \mathrm{~g})$ was sequentially partitioned into hexane $(10.0 \mathrm{~g})$, chloroform (14.8 g), ethyl acetate (2.4 g), and water $(12.8 \mathrm{~g})$ portions for subsequent bioassay. The organic solvent portions were concentrated to dryness by rotary evaporation at $45^{\circ} \mathrm{C}$, and the water portion was freeze-dried.

Isolation procedures for constituents of $A$. gramineus rhizomes active against test insects were performed as previously described (Park, 2000). For isolation, 2,500 ppm of each A. gramineus rhizome-derived fraction in acetone was applied as described below. The hexane portion $(10 \mathrm{~g})$ was chromatographed on a silica gel column (Merck 230-400 mesh, $500 \mathrm{~g}, 6 \times 80 \mathrm{~cm}$ ), and successively eluted with a stepwise gradient of chloroform/ methanol (100/0, 95/5, 90/10, 75/25, 50/50, and $0 / 100, v / v)$. Column fractions were analyzed by TLC (silica gel G), and fractions with a similar TLC pattern were pooled. The bioactive fraction (7.3 g) was successively rechromatographed on a silica gel column, using hexane/ethyl acetate $(150: 1)$. For further separation of the constituents from the active fraction $(2.3 \mathrm{~g})$, preparative highperformance liquid chromatography (HPLC) (Spectra System P2000, Thermo Separation Products) was used. The column was a 39 i.d. $\times 300 \mathrm{~mm}$ $\mu$ Bondapak $\mathrm{C}_{18}$ (Waters) with methanol/water $(3: 7)$ at a flow rate of $3 \mathrm{ml} / \mathrm{min}$ and detection at $254 \mathrm{~nm}$. Finally, two active principles $1(89 \mathrm{mg})$ and $2(23 \mathrm{mg})$ were isolated.

The structures of the active isolates were deter- mined by spectroscopic analyses. ${ }^{1} \mathrm{H}-$ and ${ }^{13} \mathrm{C}$ NMR spectra were recorded in deuteriochloroform with a BRUKER AM-500 spectrometer at 400 and $100 \mathrm{MHz}$, respectively. UV spectra were obtained in methanol with a JASCO V-550 spectrometer and EI-MS spectra on a JEOL GSX 400 spectrometer.

Bioassay. Spray method was used for $N$. lugens. Ten female adults ( 3 to 5 days old) were transferred into a test tube $(3 \times 15 \mathrm{~cm})$ containing five rice plant seedlings (7-10 days after germination) wrapped with cotton and water $(10 \mathrm{ml})$. Each $A$. gramineus rhizome-derived fraction and isolate (dissolved in $4 \mathrm{ml}$ acetone) was suspended in distilled water with Triton X-100 $(0.1 \mathrm{ml} / l)$. Controls received acetone-Triton $\mathrm{X}-100$ solution. Test material solutions were applied at a rate of $0.1 \mathrm{ml}$ per test tube by a glass spray unit connected to a forced air supply (Pacific Chemical, Seoul).

The toxicity of $A$. gramineus rhizome-derived fractions and isolates to the aphid and two lepidopteran larvae was examined by leaf dipping assay. Cabbage (Brassica oleracea L., 25 days old) leaves for 3rd instar larvae of $P$. xylostella and $S$. litura, and tobacco leaves for $M$. persicae female adults from each plant species grown in a glasshouse were collected, and discs $(5.5 \mathrm{~cm}$ in diameter) were punctured from each leaf. Leaf discs were dipped in each test solution $(20 \mathrm{ml})$ described above for $30 \mathrm{~s}$. Controls received acetone-Triton X100 solution. After drying in a fume hood for $30 \mathrm{~min}, 10$ individuals each of $P$. xylostella, $S$. litura, and $M$. persicae were separately placed onto the treated and the control leaf discs in Petri dishes $(6 \times 1.5 \mathrm{~cm})$.

Treated and control insects were held at the same conditions used for colony maintenance. Mortalities were determined $48 \mathrm{~h}$ after treatment. Test insects were considered dead if appendages did not move when prodded with a camel's hair brush. All treatments were replicated nine times.

Statistical analysis. The percentage mortality was determined and transformed to arcsine squareroot values for analysis of variance (ANOVA). Treatment means were compared and separated by Scheffe's test at $p=0.05$ (SAS Institute, 1990). Means $( \pm \mathrm{SE})$ of untransformed data are presented. 


\section{RESULTS}

\section{Identification}

When fractions obtained from the methanol extract of $A$. gramineus rhizomes were bioassayed according to direct contact application, significant differences were observed in toxicity to the insect species (Table 1). At a concentration of $2,500 \mathrm{ppm}$, the hexane fraction showed potent insecticidal activity against $N$. lugens females and P. xylostella larvae. However, moderate and weak activity against $M$. persicae females and $S$. litura larvae was observed. Purification of the biologically active constituents from the hexane fraction was done by silica gel chromatography and HPLC.

Bioassay-guided fractionation of $A$. gramineus rhizome extract afforded two active constituents identified by spectroscopic analyses, including MS and NMR, and by direct comparison with authentic compounds. The active constituents were characterized as the phenylpropenes, cis-asarone (1) and trans-asarone (2) (Fig. 1).

\section{Insecticidal activity}

The toxicity of $A$. gramineus rhizome-derived cis- and trans-asarones against $N$. lugens females was examined by spray application method (Table 2). Potencies varied according to compound and dose. cis-Asarone (1) caused 100 and 83\% mortality at 1,000 and $500 \mathrm{ppm}$, respectively, whereas<smiles>C/C=C/c1cc(OC)c(OC)cc1OC</smiles>

1<smiles>C/C=C/c1cc(OC)c(OC)cc1OC</smiles>

2
Fig. 1. Structures of the phenylpropenes, (cis)-asarone (1) and (trans)-asarone (2), insecticidal constituents of Acorus gramineus rhizome.

Table 1. Toxicity of $A$. gramineus rhizome-derived materials to four insect pests, evaluated by direct contact application

\begin{tabular}{|c|c|c|c|c|}
\hline \multirow{2}{*}{ Material $^{\mathrm{a}}$} & \multicolumn{4}{|c|}{ Mortality, $\%(\text { mean } \pm S E)^{b}$} \\
\hline & N. lugens & M. persicae & P. xylostella & S. litura \\
\hline Hexane & $100 \pm 0.0 \mathrm{a}$ & $50 \pm 3.7 \mathrm{a}$ & $100 \pm 0.0 \mathrm{a}$ & $20 \pm 2.9 \mathrm{a}$ \\
\hline Chloroform & $57 \pm 1.7 \mathrm{~b}$ & $13 \pm 3.3 b$ & $93 \pm 1.7 b$ & $0 \pm 0.0 \mathrm{c}$ \\
\hline Ethyl acetate & $10 \pm 2.9 \mathrm{c}$ & $0 \pm 0.0 \mathrm{c}$ & $27 \pm 1.7 \mathrm{c}$ & $10 \pm 1.7 \mathrm{~b}$ \\
\hline Water & $0 \pm 0.0 \mathrm{~d}$ & $0 \pm 0.0 \mathrm{c}$ & $0 \pm 0.0 \mathrm{~d}$ & $0 \pm 0.0 \mathrm{c}$ \\
\hline
\end{tabular}

${ }^{\mathrm{a}}$ Exposed to 2,500 ppm.

${ }^{\mathrm{b}}$ Means within a column followed by the same letter are not significantly different at $p=0.05$ (Scheffe's test). Mortalities were transformed to arcsine square-root before ANOVA. Means $( \pm \mathrm{SE})$ of untransformed data are reported.

Table 2. Toxicity of $A$. gramineus rhizome-derived asarones to four insect pests, evaluated by direct contact application

\begin{tabular}{|c|c|c|c|c|c|}
\hline \multirow{2}{*}{ Compound } & \multirow{2}{*}{$\begin{array}{l}\text { Conc. } \\
\text { (ppm) }\end{array}$} & \multicolumn{4}{|c|}{ Mortality, $\%(\text { mean } \pm S E)^{\mathrm{a}}$} \\
\hline & & N. lugens & M. persicae & P. xylostella & S. litura \\
\hline \multirow[t]{4}{*}{ cis-Asarone } & 2,000 & $100 \pm 0.0 \mathrm{a}$ & $53 \pm 1.7 \mathrm{a}$ & $100 \pm 0.0 \mathrm{a}$ & $13 \pm 1.7 \mathrm{ab}$ \\
\hline & 1,000 & $100 \pm 0.0 \mathrm{a}$ & $20 \pm 3.3 b$ & $83 \pm 1.7 b$ & $10 \pm 2.4 \mathrm{ab}$ \\
\hline & 500 & $83 \pm 1.7 b$ & $7 \pm 1.7 \mathrm{c}$ & $50 \pm 2.9 c$ & $11 \pm 3.5 \mathrm{ab}$ \\
\hline & 250 & $40 \pm 2.9 \mathrm{~d}$ & $0 \pm 0.0 \mathrm{~d}$ & $33 \pm 1.7 \mathrm{~d}$ & $3 \pm 1.7 b$ \\
\hline \multirow[t]{4}{*}{ trans-Asarone } & 2,000 & $100 \pm 0.0 \mathrm{a}$ & $0 \pm 0.0 \mathrm{~d}$ & $100 \pm 0.0 \mathrm{a}$ & $20 \pm 4.1 \mathrm{a}$ \\
\hline & 1,000 & $67 \pm 2.9 \mathrm{c}$ & $3 \pm 1.7 \mathrm{~cd}$ & $30 \pm 3.7 \mathrm{~d}$ & $13 \pm 1.7 \mathrm{ab}$ \\
\hline & 500 & $40 \pm 2.4 \mathrm{~d}$ & $0 \pm 0.0 \mathrm{~d}$ & $7 \pm 1.7 \mathrm{e}$ & $13 \pm 1.7 \mathrm{ab}$ \\
\hline & 250 & $13 \pm 1.7 \mathrm{e}$ & $0 \pm 0.0 \mathrm{~d}$ & $0 \pm 0.0 \mathrm{f}$ & $7 \pm 1.7 \mathrm{ab}$ \\
\hline
\end{tabular}

${ }^{a}$ Means within a column followed by the same letter are not significantly different at $p=0.05$ (Scheffés test). Mortalities were transformed to arcsine square-root before ANOVA. Means $( \pm \mathrm{SE})$ of untransformed data are reported. 
$40 \%$ mortality was achieved at $250 \mathrm{ppm}$. transAsarone (2) was much less active than cis-asarone. There was no mortality in the untreated controls.

The insecticidal activity of the test compounds against $M$. persicae females was determined by leaf dipping application method (Table 2). cis- and trans-Asarones exhibited weak or no insecticidal activity at $1,000 \mathrm{ppm}$.

Toxic effects of the test compounds on 3rd instar larvae of $P$. xylostella and $S$. litura were assessed by leaf dipping application method (Table 2). Significant differences were observed in toxicity to the lepidopteran larvae. Against P. xylostella larvae, cis-asarone showed 83 and $50 \%$ mortality at 1,000 and $500 \mathrm{ppm}$, respectively, whereas trans-asarone at $1,000 \mathrm{ppm}$ gave $30 \%$ mortality. cis- and transAsarones showed no insecticidal activity against $S$. litura larvae at 2,000 ppm. No mortality was observed in the untreated controls.

\section{DISCUSSION}

In East Asia, A. gramineus rhizomes has long been considered to have medicinal properties attributable to various constituents such as cisasarone, trans-asarone, isoasarone, caryophyllene, cis-methyl isoeugenol, and safrol (Tang and Eisenbrand, 1992). It has been reported that extracts of A. gramineus rhizomes possess insecticidal activity against adults of Sitophilus oryzae (L.), Callosobruchus chinensis (L.), and Lasioderma serricorne (F.) (Park, 2000) and N. lugens females and P. xylostella larvae (Kim et al., 2001). Bioefficacy of Acorus species against insects has been well described (Koul, 1995). In this present study, $A$. gramineus rhizome-derived materials exhibited insecticidal activity against $N$. lugens females and $P$. xylostella larvae, whereas weak activity against $M$. persicae females and S. litura larvae was observed.

It has been well recognized that plant extracts and phytochemicals can be developed into products suitable for integrated pest management because many of them are selective to pests, have no or little harmful effects on non-target organisms and the environment, act in many ways like neem extracts on various types of pest complex, and may be applied to the plant in the same way as conventional insecticides (Arnason et al., 1989a; Schmutterer, 1992; Hedin et al., 1997). Derivatives of Azadirachta indica A. Juss, belonging to the family
Meliaceae, are found to have a variety of biological activities including insecticidal activity against nearly 200 species of insects without any adverse effects on most non-target organisms (Saxena, 1989; Lowery and Isman, 1995). Additionally, certain plant-derived compounds were found to be highly effective against insecticide-resistant insect pests (Arnason et al., 1989b; Schmutterer, 1992; Ahn et al., 1997). Much concern has been focused on the distribution, nature, and practical use of plant-derived chemical substances having insecticidal activity. In the present study, the insecticidal constituents of $A$. gramineus rhizomes were identified as the phenylpropenes, cis- and trans-asarones with species selective activity. cis- and transAsarones were effective against 3rd instar larvae of $P$. xylostella but not $S$. litura. The differential susceptibility of asarones to these two lepidopteran larvae might be attributable to differences in biological factors (e.g. body weight), environmental factors (e.g. temperature), and physiological or biochemical characteristics such as penetration and detoxifying enzyme activity (e,g. mixed-function oxidases, hydrolases, and glutathione $S$-transferases) (Hollingworth, 1976; Eda, 1985). cisAsarone exhibits antifeeding and growth-inhibiting effects on larvae of Peridroma saucia (Hübner) (Koul et al., 1990), antigonadal activity against some insect species (Saxena et al., 1977; Matolcsy et al., 1981; Schmidt and Brochers, 1981), repellent effects on many insects (Koul et al., 1990), and attractant effects for Ceratitis capitata (Wiedemann), Dacus cucurbita (Coquilett), and D. dorsalis (Hendel) (Jacobson et al., 1976). In contrast, trans-asarone has antifeeding and growth-inhibiting effects on larvae of $P$. saucia (Koul et al., 1990), oviposition-stimulating effects on the carrot rustfly (Stadler and Buser, 1984), and feedingdeterrent activity against some stored foods Coleoptera (Poplawski et al., 2000).

Structure-activity relationships in insects have been well studied. Park (2000) reported that the insecticidal activity of cis-asarone was more pronounced against adults of $S$. oryzae, $C$. chinensis, and L. serricorne than that of trans-asarone. It has been well established that changes in the phenyl substituents influence the chemosterilant activity of asarones against Dysdercus koenigii (Walk) significantly (Saxena et al., 1977). In this study, cisasarone was a more potent insecticidal agent 
against $N$. lugens females and P. xylostella larvae than trans-asarone. These results indicate that the toxicity of asarones might be due to the cis configuration rather than to the position of the double bond.

Results of this and earlier studies indicate that $A$. gramineus rhizome-derived materials against $N$. lugens and P. xylostella can be developed as insectcontrol agents or lead compounds. However, cisasarone is known to possess in vivo hepatocarcinogenic effects (Wiseman et al., 1987), in vitro mutagenic activity against Salmonella typhimurium TA 100 (Gogglemann and Schimmer, 1983), and effects of induction of structural chromosome aberrations in human lymphocytes in vitro (Abel, 1987), whereas trans-asarone has sister-chromatid exchange induction effects in vivo and in vitro (Morales-Ramirez et al., 1992) and in vivo hepatocarcinogenic effects (Wiseman et al., 1987). Direct use of asarones as insecticides would not be allowed due to the above mentioned chronic toxicity, although they have low acute toxicity to mammals (Budavari et al., 1989). For practical use of these compounds as novel insecticides, further studies are essential to evaluate the hazards of natural and synthetic asarone analogs to workers during application of the compounds or consumers from residual materials on crops, their exact mode-of-action, and their effects on non-target organisms and the environment.

\section{ACKNOWLEDGEMENTS}

This research was supported by grants from the Ministry of Education (Brain Korea 21 Project) and the Ministry of Agriculture and Forestry through the R\&D Promotion Center for Agriculture and Forestry to YJA.

\section{REFERENCES}

Abel, G. (1987) Chromosomensch digende Wirkung von $\beta$ Asarone in menschlichen Lymphocyten. Planta Med. 53: 251-253.

Ahn, Y. J., M. Kwon, H. M. Park and C. G. Han (1997) Potent insecticidal activity of Ginkgo biloba-derived trilactone terpenes against Nilaparvata lugens. In Phytochemical for Pest Control Agents (P. A. Hedin, R. Hollingworth, J. Miyamoto, E. Masler and D. Thompson eds.). Am. Chem. Soc. Symp. Ser. 658, Washington, D.C., pp. 90-105.

Arnason, J. T., B. J. R. Philogène and P. Morand (1989a) Insecticides of Plant Origin. Am. Chem. Soc. Symp. Ser. 387, Washington, D.C. 213 pp.

Arnason, J. T., B. J. R. Philogène, P. Morand, K. Imrie, S. Iyengar, F. Duval, C. Soucy-Breau, J. C. Scaiano, N. H. Wer- stiuk, B. Hasspieler and A. E. R. Downe (1989b) Naturally occurring and synthetic thiophenes as photoactivated insecticides. In Insecticides of Plant Origin (J. T. Arnason, B. J. R. Philogène and P. Morand eds.). Am. Chem. Soc. Symp. Ser. 387, Washington, D.C., pp. 164 172.

Brown, A. W. A. (1978) Ecology of Pesticides. Academic Press, New York. 525 pp.

Budavari, S. B., M. J. O’Neil, A. Smith and P. E. Heckelman (1989) The Merck Index. Merck \& Co., Rahway, New Jersey.

Eda, S. (1985) In vivo kenteiho. In Noyakuseibutsukenteiho (T. Hosotsuji ed.). Zenno, Tokyo, pp. 232-271 (in Japanese).

Georghiou, G. P. and T. Saito (1983) Pest Resistance to Pesticides. Plenum Press, New York. 809 pp.

Gogglemann, W. and O. Schimmer (1983) Mutagenicity testing of $\beta$-asarone and commercial calamus drugs with Salmonella typhimurium. Mutat. Res. 121: 191-194.

Hayes, J. B. Jr. and E. R. Laws, Jr. (1991) Handbook of Pesticide Toxicology, Vol. 1. Academic Press, San Diego. 496 pp.

Hedin, P. A., R. Hollingworth, J. Miyamoto, E. Masler and D. G. Thompson (1997) Phytochemicals for Pest Control. Am. Chem. Soc. Symp. Ser. 658, Washington, D.C. 372 pp.

Hollingworth, R. M. (1976) The biochemical and physiological basis of selective toxicity. In Insecticide Biochemistry and Physiology (C. F. Wilkinson ed.). Plenum Press, New York, pp. 431-506.

Im, D. J., B. S. Park, B. R. Jin, K. M. Choi and S. K. Kang (1988) Pathogenicity of nuclear polyhedrosis virus isolated from the tobacco cutworm, Spodoptera litura. Korean J. Appl. Entomol. 27: 219-224 (in Korean with English summary).

Isman, M. B. (1995) Leads and prospects for the development of new botanical insecticides. Rev. Pestic. Toxicol. 3: $1-20$.

Jacobson, M. (1989) Botanical pesticides: past, present, and future. In Insecticides of Plant Origin (J. T. Arnason, B. J. R. Philogène and P. Morand eds.). Am. Chem. Soc. Symp. Ser. 387, Washington, D.C. pp. 1-10.

Jacobson, M., I. Keiser, D. H. Miyashita and E. J. Harris (1976) Indian calamus root oil: attractiveness of the constituents to oriental fruit flies, melon flies and Mediterranean fruit flies. Lloydia 39: 412-415.

Kim, S. I., O. K. Shin, C. Song, K. Y. Cho and Y. J. Ahn (2001) Insecticidal activities of aromatic plant extracts against four agricultural insects. Agric. Chem. Biotechnol. 44: 23-26.

Koul, O. (1995) Acorus allelochemicals, chemistry and bioefficacy against insects. In Pesticides, Crop Protection and Environment (B. S. Parmar and S. Walia eds.). Oxford and IBH Publishers, New Delhi, pp. 99-113.

Koul, O., M. J. Smirle and M. B. Isman (1990) Asarones from Acorus calamus L. oil. Their effect on feeding behavior and dietary utilization in Peridroma saucia. J. Chem. Ecol. 16: 1911-1920.

Lowery, D. T. and M. B. Isman (1995) Toxicity of neem to natural enemies of aphids. Phytoparasitica 23: 297-306. 
Matolcsy, G., A. I. Farag, L. Varjas, I. Belai and Y. M. Darwish (1981) Morphogenetic and chemosterilant activity of asarone analogues. In Juvenile Hormone Biochemistry (G. E. Pratt and G. T. Brooks eds.). Elsevier/North Holland Biomedical Press, Amsterdam, Netherlands, pp. 383-402.

Miyakado, M., I. Nakayama and N. Ohno (1989) Insecticidal unsaturated isobutylamides: from natural products to agrochemical leads. In Insecticides of Plant Origin (J. T. Arnason, B. J. R. Philogène and P. Morand eds.). Am. Chem. Soc. Symp. Ser. 387, Washington, D.C., pp. 173187.

Morales-Ramirez, P., E. Madrigal-Bujaidar, J. Mercader-Martinez, M. Cassini, G. Gonzalez, G. Chamorro-Cevallos and M. Salazar-Jacobo (1992) Sister chromatid exchange induction produced by in vivo and in vitro exposure to $\alpha$ asarone. Mutat. Res. 279: 269-273.

Park, C. (2000) Insecticidal activity of $\beta$-asarone derived from Acorus gramineus rhizome against insect pests. MS thesis, Seoul National University, Suwon, Republic of Korea. $93 \mathrm{pp}$.

Poplawski, J., B. Lozowicka, A. T. Dubis, B. Lachowska, Z. Winiecki and J. Nawrot (2000) Feeding-deterrent activity of $\alpha$-asarone isomers against some stored Coleoptera. Pest Menag. Sci. 56: 560-564.

SAS Institute (1990) SAS/STAT User's Guide, Version 6. SAS Institute, Cary, North Carolina.

Saxena, B. P. (1989) Insecticides from neem. In Insecticides of
Plant Origin (J. T. Arnason, B. J. R. Philogène and P. Morand eds.). Am. Chem. Soc. Symp. Ser. 387, Washington, D.C. pp. 110-135.

Saxena, B. P., O. Koul, K. Tikku and C. K. Atal (1977) A new insect chemosterilant isolated from Acorus calamus L. Nature 270: 512-513.

Schmidt, G. S. and D. Brochers (1981) Studies of the sterilizing effect of Indian Acorus calamus in ants. Mitt. Dtsch. Ges. Allg. Angew. Entomol. 3: 201-213.

Schmutterer, H. (1992) Control of diamondback moth by application of neem extracts. In Diamondback Moth and Other Crucifer Pests (N. S. Talekar ed.). Proceedings, 2nd International Workshop, Asian Vegetable Research and Development Center, Taipei, Taiwan, pp. 325-332.

Stadler, E. and H. R. Buser (1984) Defense chemicals in leaf surface wax synergistically stimulate oviposition by a phytophagous insect. Experientia 40: 1157-1159.

Tang, W. and G. Eisenbrand (1992) Chinese Drugs of Plant Origin. Springer, New York. 1,056 pp.

Wink, M. (1993) Production and application of phytochemicals from an agricultural perspective. In Phytochemistry and Agriculture (T. A. van Beek and H. Breteler eds.). Clarendon Press, Oxford, pp. 171-213.

Wiseman, R. W., E. C. Miller, J. A. Miller and A. Liem (1987) Structure-activity studies of the hepatocarcinogenicities of alkenylbenzene derivatives related to estragole and safrole on administration of preweanling male $\mathrm{C} 57 \mathrm{BL} / 6 \mathrm{~J} \times$ C3H/HeJ F1 mice. Cancer Res. 47: 2275-2283. 